\begin{tabular}{|l|l|l|l|l|l|} 
J. Tek. Ling & Vol.11 & No.3 & Hal. 425 - 433 & Jakarta, September 2010 & ISSN 1441-318X \\
\hline
\end{tabular}

\title{
KEMAMPUAN Flavobacterium sp NUB1 DALAM MENGGUNAKAN ALIFATIK NITRIL UNTUK PERTUMBUHANNYA
}

\author{
Nunik Sulistinah \\ Bidang Mikrobiologi, Pusat Penelitian Biologi-LIPI \\ Cibinong Science Center, Jl Raya Jakarta-Bogor km 46 Cibinong \\ E-mail: listin_ar @yahoo.com
}

\begin{abstract}
A bacteria isolate capable utilizing $1 \%(\mathrm{v} / \mathrm{V})$ acetonitrile and butironitrile as thesole source of carbon and nitrogen was isolated from industrial effluents ofPT Petrokimia-Gresik and identified as Flavobacterium sp NUB1. The bacteriaisolate was able to grow in both acetonitrile and butironitrile at concentrationof up to $4 \%(\mathrm{v} / \mathrm{V})$. The highest growth was reached at $1 \%$ concentration ofacetonitrile and butironitrile, but the bacteria isolate was not able to grow onacrilonitrile. The specific growth rate $(\mu)$ of the isolate was $0,029 \mathrm{~h}-1$. Themajor objective of this study was to explore the abilities of the isolate to utilizesome aliphatic nitriles and then further evaluate the metabolite product of thenitrile degradation.
\end{abstract}

Key words: aliphatic nitrile, biodegradation, Flavobacterium sp. NUB1

\section{PENDAHULUAN}

\subsection{Latar Belakang}

Senyawa nitril merupakan senyawa organik yang mengandung $\mathrm{CN}$ pada struktur molekulnya $(-\mathrm{C}=\mathrm{N})$. Senyawa ini tersebar luas di lingkungan. Di alam, sebagian besar nitril berada dalam bentuk sianoglikosida yang dihasilkan/ diproduksi oleh tanaman (Miller \& Conn, 1980) ${ }^{11}$. Selain itu, sebagian besar tanaman juga menghasilkan senyawa nitril yang lain, seperti sianolipid, risinin, phenilasetonitril dsb. Sedangkan industriindustri kimia menggunakan nitril secara ekstensif untuk memproduksi macammacam polimer. Nitril juga banyak diproduksi secara industri sebagai bahan intermediet dan bangunan. Sebagian besar senyawa nitril merupakan senyawa hidropobik yang toksik dan beberapa diantaranya sulit untuk didegradasi (Sorokin et al., 2007)2). Atas dasar itu, penggunaan senyawa nitril secara ekstensif dapat menimbulkan masalahmasalah lingkungan (Rezende et al., 1999). Oleh karena itu, peran enzim pendegradasi nitril sangat penting untuk mendetoksifikasi atau paling tidak meminimasi keberadaan senyawa tersebut dilingkungan.

Secara umum, ada 2 enzim yang berperan dalam biokonversi senyawa nitril menjadi asam karboksilat. Metaloenzim nitril hidratase menghidrolisis sebagian besar nitril alifatik, arilalifatik dan aromatik menjadi 
amida (R-CONH2 ) yang selanjutnya dapat dikonversi menjadi asam-asam karboksilat dan ammonium oleh enzim amidase. Dilaporkan organisme-organisme yang memproduksi nitril hidratase pada umumnya juga memproduksi amidase (Kobayashi \& Shimizu,1998; Sorokin et al., 2007)3). Enzim pendegradasi yang lain adalah nitrilase yang mengkatalisis senyawa nitril ( $R C N$ ) secara langsung menjadi asam karboksilat dan ammonium tanpa menghasilkan amida sebagai produk. Enzim nitrilase pada umumnya menghidrolisis sebagian besar senyawa nitril aromatik.

Pemanfaatan mikroba yang mampu memproduksi enzim-enzim tersebut sangat mendapat perhatian oleh karena enzimenzim yang dihasilkan sangat potensial sebagai biokatalis dan juga dapat digunakan untuk sintesis senyawa-senyawa organik secara enansioselektif, serta sebagai agent bioremediasi lingkungan (Blakey et al., 1995; Banerjee et al., 2002; Håkansson et al., 2005; Kohyama et al., 2006; Manolov et al., 2005 ). Beberapa strain bakteri dan jamur dilaporkan sebagai penghasil enzim pendegradasi/ penghidrolisis nitril, seperti misalnya Genus Rhodococcus yang termasuk dalam kelompokA c t i n o b a c t e r i a d i l a p o r k a n memproduksi enzim nitril hidratase dan nitrilase ( Kobayashi \& Shimizu. 1998). $\left.{ }^{4}\right)$

Sejauh ini diketahui bahwa mikroba pendegradasi nitril adalah dari kelompok neutrofilik, mikroba tersebut tumbuh optimal pada $\mathrm{pH}$ netral. Sementara dilaporkan oleh Sorokin et al, 2007 bahwa Natrocella acetinitrilica yang diisolasi dari "soda lake sediment" mampu tumbuh dan memanfaatkan asetonitril dan propionitril sebagai satusatunya sumber karbon, energi dan nitrogen dibawah kondisi "haloalkaline". Enzim penghidrolisis nitril pada kondisi alkaline yang sangat tinggi mungkin mempunyai kelebihan, terutama ketika senyawa sianida terlibat dalam proses reaksi degradasi tersebut, seperti misalnya pada reaksi Strecker: hidrolisis á-aminonitrile secara enansioselektif menjadi $\alpha$ - aminoamides and a-amino acids (Duthaler, 1994). ${ }^{5 \text { ) }}$

\subsection{Tujuan}

Tujuan utama dari eksperimen ini adalah untuk mengeksplor kemampuan Flavobacterium NUB1 dalam menggunakan beberapa senyawa alifatik nitril sebagai substrat pertumbuhannya yang selanjutnya mengevaluasi reaksi transformasi dengan mengukur salah satu produk metabolitnya yaitu ammonium.

\section{BAHAN DAN METODE}

\subsection{Mikroba}

Isolat bakteri yang digunakan dalam penelitian ini adalah Flavobacterium sp NUB1 dan Flavobacterium sp ASP yang masing-masing diisolasi dari limbah PT Petrokimia Gresik dan limbah kilang minyak Sungai Gerong Plaju- Palembang.

\subsection{Bahan Kimia}

Bahan-bahan kimia yang digunakan dalam penelitian ini adalah produk dari Merck (Acetonitril dan Butironitril),Akrilonitril (Aldrich).

\subsection{Komposisi media kultivasi}

Media yang digunakan untuk menumbuhkan Flavobacterium sp NUB1 adalah media mineral dengan komposisi sebagai berikut: Na2HPO4 0,357g, KH2PO4 $0,1 \mathrm{~g}, \mathrm{MgSO} 4.7 \mathrm{H} 2 \mathrm{O} 0,1 \mathrm{~g}, \mathrm{CaCl} 2.2 \mathrm{H} 2 \mathrm{O}$ $0,01 \mathrm{~g}, \mathrm{FeSO} 4.7 \mathrm{H} 2 \mathrm{O}$ 0,001g, yeast extract $0,01 \mathrm{~g}$, Mikroelemen 1,0 ml, Aquadest ditambahkan sampai volume $1000 \mathrm{ml}$ (Meyer \& Schlegel, 1983; Pfennig, 1974). Komposisi mikroelemen adalah sebagai berikut: $\mathrm{ZnSO} 4.7 \mathrm{H} 2 \mathrm{O}, \mathrm{MnCl} 2.4 \mathrm{H} 2 \mathrm{O}$, $\mathrm{H} 3 \mathrm{BO} 3, \mathrm{CoCl} 2.6 \mathrm{H} 2 \mathrm{O}, \mathrm{CuCl} 2.2 \mathrm{H} 2 \mathrm{O}, \mathrm{NiCl}$. $6 \mathrm{H} 2 \mathrm{O}, \mathrm{Na} 2 \mathrm{MO} 4.2 \mathrm{H} 2 \mathrm{O}, \mathrm{Na} 2 \mathrm{SeO} 3$ Sebagai sumber karbon dan nitrogen digunakan asetonitril dan butironitril masing-masing dengan konsentrasi $1 \%(\mathrm{v} / \mathrm{v})$. 


\subsection{Penentuan pertumbuhan Flavobacterium sp.}

Pertumbuhan Flavobacterium sp. selama proses fermentasi ditentukan dengan menggunakan satuan kerapatan optis (OD) pada panjang gelombang $436 \mathrm{~nm}$. Laju pertumbuhan spesifik $(\mu)$ isolate ditentukan berdasarkan persamaan berikut: $\mu=2,303$ $\log 2$ x 1/td (Marison, 1988).

\subsection{Pengujian Flavobacterium sp NUB1 pada asetonitril, butironitril, dan akrilonitril sebagai sumber energi, karbon, dan/atau nitrogen}

Penggunaan asetonitril dan butironitril sebagai satu-satunya energi, karbon, dan nitrogen diuji dengan menumbuhkan isolat bakteri uji pada asetonitril, butironitril dan akrilonitril. Penggunaan senyawa nitril alifatik sebagai sumber energi dan karbon diuji dengan menumbuhkan isolat bakteri tersebut pada asetonitril, butironitril, akrilonitril dan $\mathrm{NH} 4 \mathrm{Cl}$. Sedangkan penggunaan asetonitril, butironitril, dan akrilonitril sebagai sumber nitrogen saja diuji dengan menumbuhkan isolat bakteri pada asetonitril, butironitril, akrilonitril dan glukosa. Kultur diinkubasi di atas mesin pengocok (shaker) pada suhu kamar selama waktu tertentu. Pertumbuhan kultur diamati pada jam ke 0, 48, dan 96 .

\subsection{Pengujian pengaruh berbagai konsentrasi asetonitril dan butironitril terhadap pertumbuhan Flavobacterium sp NUB1}

Isolat yang mampu memanfaatkan senyawa alifatik nitril (asetonitril dan butironitril sebagai satu-satunya sumber energi, karbon, dan nitrogen ditumbuhkan pada kedua senyawa nitril tersebut dengan kisaran konsentrasi 0\%-4\% dan diinkubasi selama \pm 7 hari

\subsection{Penentuan Pola pertumbuhan Flavobacterium sp}

Pertumbuhan Flavobacterium sp NUB1 dilakukan dalam Erlenmeyer (1000 ml) berisi $500 \mathrm{ml}$ media pertumbuhan yang mengandung asetonitril $1 \%(\mathrm{v} / \mathrm{v})$. Kultur diinkubasi di atas mesin pengocok (shaker) pada suhu kamar ( \pm 28 oC) selama 72 jam. Setiap 3 jam, sample diambil untuk penentuan pertumbuhan, perubahan $\mathrm{pH}$, dan konsentrasi amonium $(\mathrm{NH} 4+)$ yang terbentuk.

\subsection{Produksi biomassa sel}

Biomassa sel diproduksi dalam $1000 \mathrm{ml}$ erlenmeyer berisi $500 \mathrm{ml}$ media pertumbuhan yang mengandung asetonitril $1 \%$. Kultur diinkubasi pada suhu kamar dan sel dipanen pada waktu produksi sel optimum ( \pm 72 jam). Sel dipanen dengan cara mensentrifuse kultur dengan kecepatan 10.000 rpm selama 15 menit pada suhu 4 oC. Pelet yang diperoleh dicuci dengan $50 \mathrm{mM}$ buffer fosfat (KH2PO4) pH 7,2 sebanyak 2 kali. Pelet yang diperoleh digunakan untuk penentuan karakterisasi enzim dalam sel utuh (whole cells).

\subsection{Penentuan aktivitas enzim}

Campuran reaksi yang telah mengandung $1,5 \%$ sel $\mathrm{b} / \mathrm{v}$, asetonitril $1 \%$ (untuk $\mathrm{NH}$-ase) atau asetamide (untuk amidase) dalam $50 \mathrm{mM}$ (KH2PO4) pH 7,2 diinkubasi selama 15 menit pada suhu kamar $\left(30^{\circ} \mathrm{C}\right)$. Pengambilan sampel sebanyak $1000 \mu$ l dilakukan pada menit ke $0,15,30$, $45,60,75,90,120,150$, dan 180. Aktivitas enzim dihentikan dengan penambahan 0,25 $\mathrm{ml} \mathrm{HCl} 4 \mathrm{~N}$. Sampel kemudian disentrifuse selama 10 menit pada kecepatan 15000 rpm. Kadar ammonium ( $\mathrm{NH} 4+$ ) dalam supernatan ditentukan dengan metode Nessler. 
2.10. Penentuan konsentrasi ammonium sebagai salah satu produk hidrolisis

Konsentrasi ammonium ditentukan secara kolorimetris dengan menggunakan metode Nessler. Supernatan sampel (100 $\mu \mathrm{l})$ ditambahkan ke dalam $990 \mu \mathrm{l} 0,1 \mathrm{~N}$ $\mathrm{NaOH}$. Ke dalam larutan tersebut kemudian ditambahkan $200 \mu$ l pereaksi Nessler, dihomogenkan dan diinkubasi selama 20 menit. Larutan tersebut selanjutnya diukur pada panjang gelombang $400 \mathrm{~nm}$. Kosentrasi ammonium dalam sampel dihitung berdasarkan kurva standar.

\subsection{Pereaksi Nessler}

5,0 g KI (Kalium lodid) dilarutkan dalam aquabidest (air bebas ammonia) dan kemudian ditambahkan larutan $\mathrm{HgCl} 2(2,0$ $\mathrm{g} \mathrm{HgCl} 2$ dalam $35 \mathrm{ml}$ aquabidest) sampai membentuk endapan yang berwarna orange. Selanjutnya larutan ditambahkan larutan $5 \mathrm{~N}$ $\mathrm{NaOH}$ sebanyak $20 \mathrm{ml}$ (Gerhardt \& Drew, 1994).

\section{HASIL DAN PEMBAHASAN}

\subsection{Pertumbuhan Flavobacterium sp NUB1 pada alifatik nitril}

Hasil pengujian menunjukkan, bahwa Flavobacterium sp NUB1 mampu tumbuh dan menggunakan kedua senyawa nitril alifatik (asetonitril dan butironitril) sebagai satu-satunya sumber karbon, energi, dan nitrogen untuk pertumbuhannya. Namun isolat bakteri tersebut tidak mampu menggunakan akrilonitril dengan baik sebagai sumber karbon, energi, dan nitrogen (Gambar 1 A, B \& C ). K e t i d a k m a m p u a n Flavobacterium sp NUB1 tumbuh pada akrilonitril disebabkan toksisitas akrilonitril lebih tinggi dibandingkan senyawa asetonitril dan butironitril. Dilaporkan, bahwa isolasi mikroba pendegradasi akrilonitril sangat sulit dilakukan karena akrilonitril tergolong sangat toksik sehingga mikroba sulit tumbuh (Yamada \& Kobayashi, 1996). Disamping itu stuktur akrilonitril mempunyai ikatan ganda dua atom $\mathrm{C}$ nomor satu dan atom $\mathrm{C}$ nomor dua (nitrilalifatik tidak jenuh) sehingga mikroba sulit mendegradasi senyawa ini (Purnomo,2000).

Penggunaan glukosa sebagai sumber karbon dan penggunaan amonium khlorida sebagai sumber nitrogen juga ditampilkan pada Gambar 1A, B, dan C. Nampak bahwa penggunaan glukosa sebagai sumber karbon dan penggunaan $\mathrm{NH} 4 \mathrm{Cl}$ sebagai sumber karbon tidak meningkatkan pertumbuhan Flavobacterium sp. NUB1 pada akrilonitril. Hal ini membuktikan bahwa isolat bakteri tersebut hanya mampu menggunakan asetonitril/ butironitril sebagai satu-satunya sumber karbon, energi, dan/atau nitrogen.

Beberapa alasan yang menguatkan bahwa Flavobacterium sp NUB1 dapat tumbuh pada butironitril/alifatik nitril adalah induksi enzim nitril hidratase dan amidase oleh senyawa nitril pada mikroba. Umumnya induksi terjadi pada saat diberi senyawa

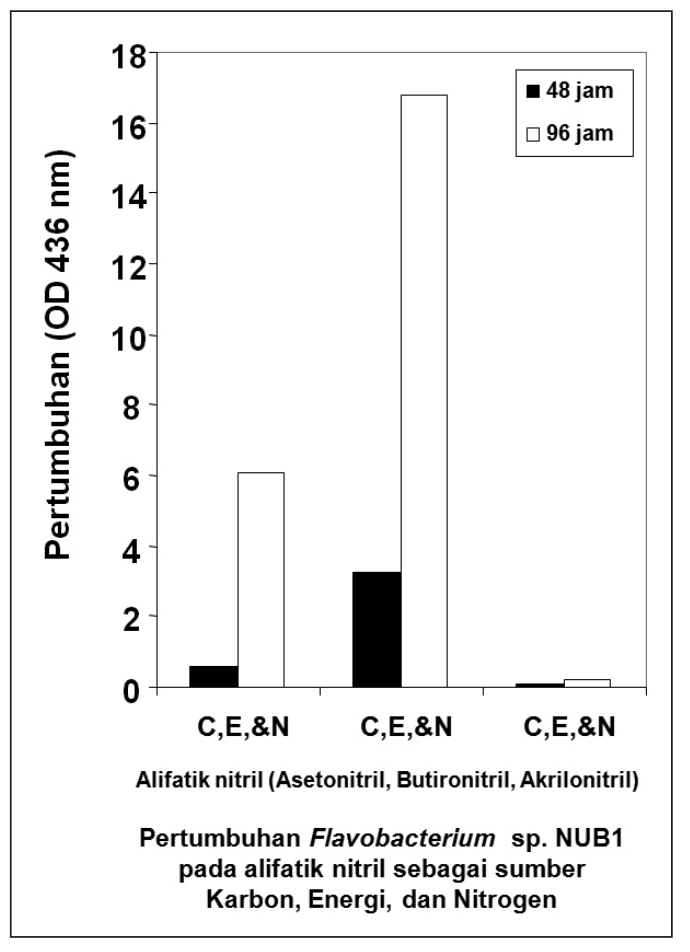




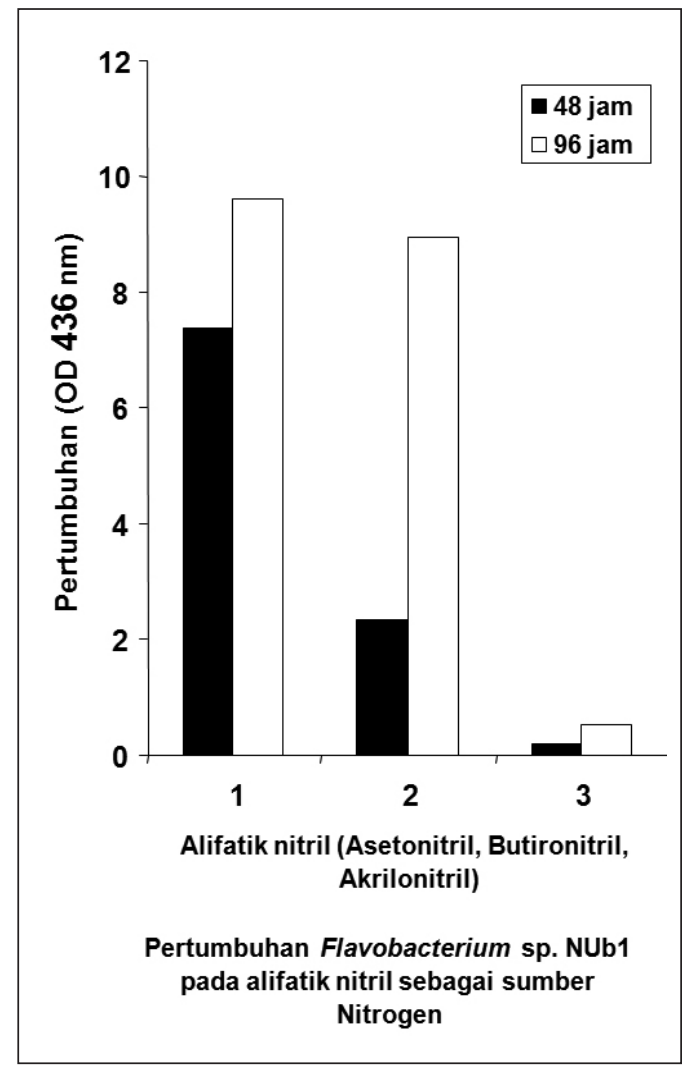

Gambar 1 : A, B dan C. Pertumbuhan Flavobacterium sp. NUB1 pada alifatik nitril (asetonitril $1 \%$, butironitril $1 \%$, akrilonitril $0,01 \%)$.

alifatik dengan berat molekul rendah, seperti asetonitril, butironitril, sedangkan enzim nitrilase cenderung menggunakan penginduksi senyawa nitril aromatik (Yamada, 1996; Kobayashi, 1994). Sifat enzim nitril hidratase dan amidase bekerja secara luas (Layh et al., 1995), sehingga dapat dimungkinkan diperoleh enzim nitril hidratase dan amidase yang merupakan enzim pendegradasi nitril.

Pengujian pengaruh konsentrasi asetonitril dan butironitril terhadap pertumbuhan Flavobacterium sp NUB1 ditampilkan pada Gambar 3 A\&B . Pada Gambar tersebut terlihat bahwa Flavobacterium sp NUB 1 mampu tumbuh pada asetonitril dan butironitril hingga konsentrasi

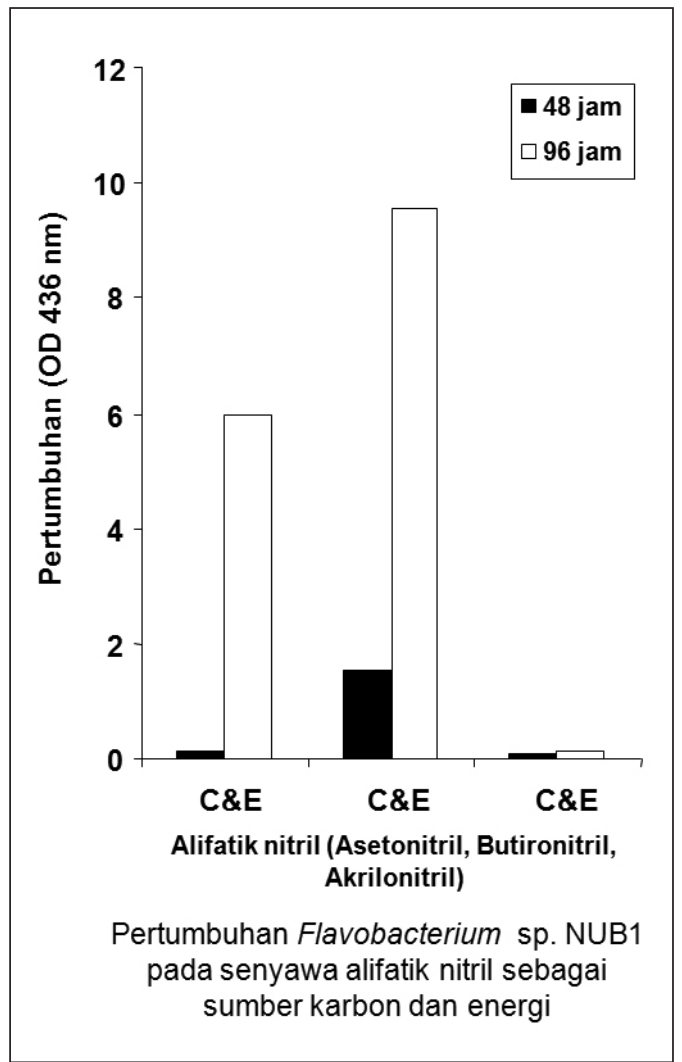

4\% (v/v) dengan pertumbuhan maksimal masing-masing pada $1 \%(\mathrm{v} / \mathrm{v})$. Peningkatan konsentrasi butironitril menghambat pertum bu h a n Flavobacterium sp NUB1, sedangkan pertumbuhanFlavobacterium sp. NUB1 pada kisaran konsentrasi asetonitril 1-4\% relatif lebih baik dibandingkan pertumbuhannya pada butironitril. Dengan demikian asetonitril merupakan substrat yang baik untuk pertumbuhan isolat bakteri tersebut.

\subsection{Pola Pertumbuhan Flavobacterium sp NUB1 pada Asetonitril dan Butironitril}

Pola pertumbuhan Flavobacterium $\mathrm{sp}$ NUB1 ditentukan dengan cara menumbuhkan isolat bakteri tersebut pada media mineral yang mengandung $1 \%(\mathrm{v} / \mathrm{v})$ senyawa alifatik nitril (asetonitril/ butironitril) sebagai satusatunya sumber karbon, energi dan nitrogen 
untuk pertumbuhannya. Pola pertumbuhan Flavobacterium sp NUB1 ditunjukkan pada Gambar 4. Pada gambar tersebut memperlihatkan, bahwa pertumbuhan Flavobacterium sp.

NUB1 baik pada asetonitril maupun butironitril diawali dengan fase lagi yang relatif cukup panjang yaitu selama $\pm 9-10$ jam. Pertumbuhan bakteri pada fase ini masih lambat karena bakteri masih beradaptasi dengan lingkungan medianya. Terbentuknya amonium yang dihasilkan merupakan indikasi, bahwa senyawa nitril yang diuji telah mengalami penguraian menjadi amida dan asam karboksilat (Digeronimo \& Antoinie,1976). Dilaporkan, bahwa metabolisme senyawa alifatik nitril oleh mikroba melalui dua tahap reaksi yang berbeda dan melibatkan dua enzim yang berbeda pula. Tahap reaksi pertama melibatkan enzim nitril hidratase $(\mathrm{NH}-$ ase) mengubah nitril menjadi amida dan reaksi selanjutnya amida yang terbentuk akan diubah menjadi asam karboksilat dan amonia oleh enzim amidase. Fase eksponensial dicapai dalam jangka waktu yang relatif lama yaitu sekitar 56 jam. Pada fase eksponensial terjadi pertumbuhan yang sangat cepat. Populasi meningkat drastis dan mengikuti persamaan eksponensial dan terjadi peningkatan $\mathrm{pH}$. $\mathrm{pH}$ mengalami kenaikan oleh karena mikroba belum memanfaatkan seluruh amonium yang terbentuk untuk metabolismenya.

\subsection{Degradasi alifatik nitril dengan menggunakan resting cell Flavobacterium sp. NUB1}

Kemampuan Flavobacterium sp. NUB1 dalam mensintesis enzim pendegradasi alifatik nitril dapat diketahui secara tidak langsung dengan cara mengukur kadar amonium (Nawaz et al., 1992). Amonium yang terbentuk pada degradasi alifatik nitril dengan resting cell Flavobacterium sp. NUB1 ditampilkan pada Gambar 5. Gambar tersebut menunjukkan, bahwa konsentrasi



Gambar 2 : Pertumbuhan, perubahan $\mathrm{pH}$, dan amonium selama proses fermentasi Flavobacterium sp. NUB1 pada Butironitril 1\% 

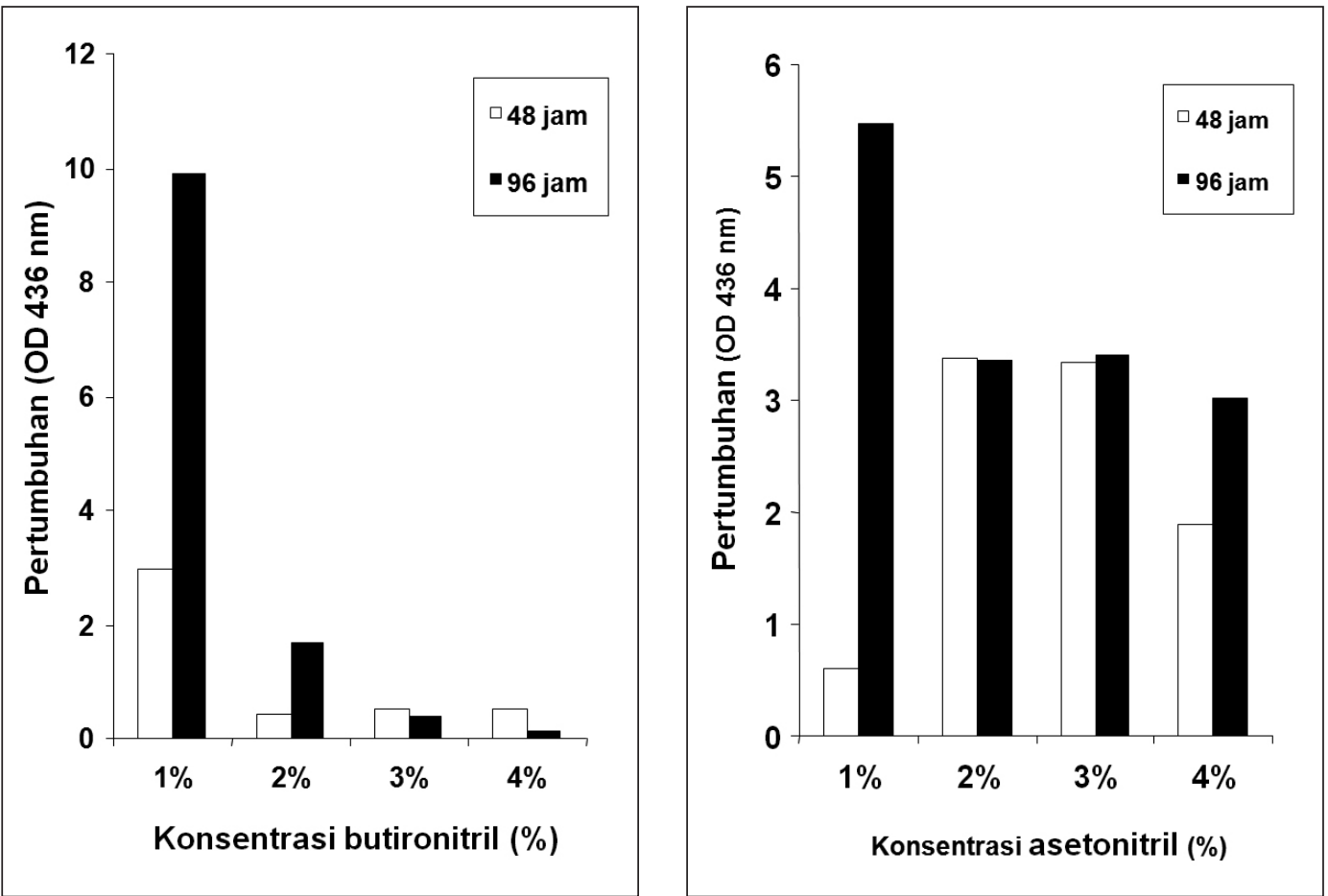

Gambar 3 : A dan B. Pengaruh konsentrasi Asetonitril (A) dan Butironitril (B) terhadap pertumbuhan Flavobacterium sp. NUB1.

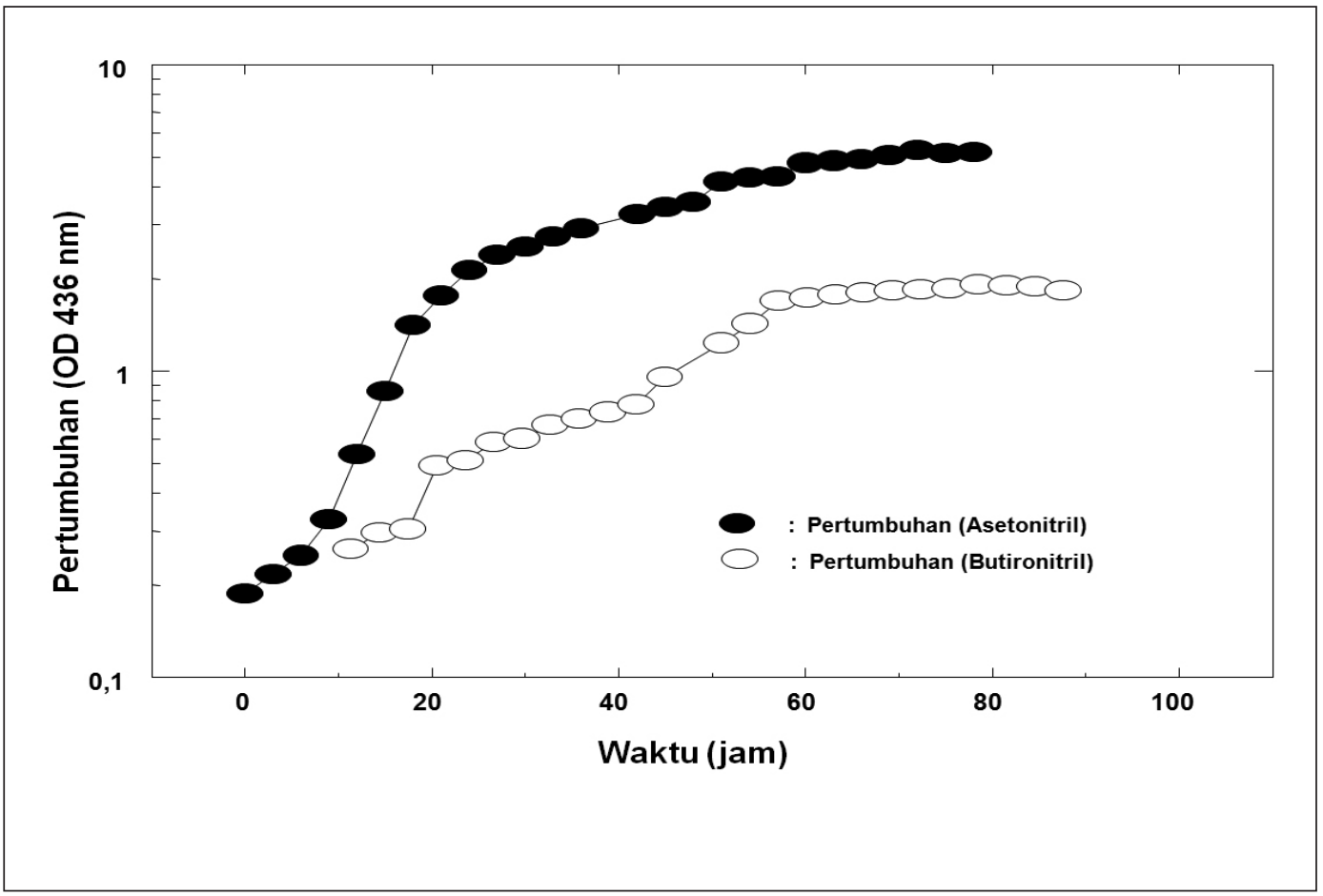

Gambar 4 : Pertumbuhan Flavobacterium sp. NUB1. pada Asetonitril (1\%) dan Butironitril (1\%) 




Gambar 5 : Pembentukan amonium pada degradasi Asetonitril dan Butironitril dengan menggunakan resting cell flavobacterium sp. NUB1

amonium meningkat dengan meningkatnya waktu inkubasi.

Konsentrasi amonium yang terukur selama 90 menit inkubasi adalah sebesar $11,65 \mathrm{mM}$ untuk asetonitril dan 7,285 mM untuk butironitril. Amonium yang terbentuk mengindikasikan bahw a Flavobacterium sp NUB1 mampu mensintesis enzim pendegradasi nitril.

\section{KESIMPULAN}

Dari hasil eksperimen ini dapat disimpulkan, bahwa Flavobacterium sp NUB1 yang di isolasi dari PT Petrokimia -Gresik mampu memanfaatkan asetonitril dan butironitril sebagai satu-satunya sumber energi, karbon, dan nitrogenuntuk substrat pertumbuhannya.

Isolat tersebut juga mampu tumbuh pada kedua senyawa nitril tersebut sampai dengan $4 \%(\mathrm{v} / \mathrm{v})$ dengan pertumbuhan optimal pada konsentrasi $1 \%$. Laju pertumbuhan spesifik $(\mu)$ 0,029 h-1. Degradasi alifatik nitril oleh Flavobacterium sp. NUB1 menghasilkan produk berupa amonia. Dibandingkan akrilonitril dan butironitril, asetonitril merupakan sumber energi, karbon, dan nitrogen yang terbaik untuk Flavobacterium sp. NUB1.

\section{DAFTAR PUSTAKA}

1. Banerjee, A., R. Sharma, and U. C. Banerjee, 2002. The nitriledegrading enzymes: current status and future prospects. Appl. Microbiol. Biotechnol. 60:33-44.

2. Blakey, A. J., J. Colby, E. Williams, and C. O'Reilly, 1995. Regioand stereospecific nitrile hydrolysis by the nitrile hydratase from Rhodococcus AJ270. FEMS Microbiol. Lett. 129:57-62

3. Digeronimo, M.J. and A.D. Antoine,1976. Metabolism of Acetonitrile and Propionitrile by Nocardia rhodochrous LL100-21. Appl. Environ. Microbiol.31 (6) : 900-906.

4. Duthaler, R. O. 1994. Recent developments in the stereoselective synthesis of áaminoacids. Tetrahedron 50:1539-1650. 
5. Gerhardt, P. \& S.W. Drew, 1994. Liquid Culture. In : Gerhardt, P., Murray, R.G.E., Wood, WA. \& Krieg, N.R. (eds). Methods for General and Molecular Bacteriology. ASM., Washington, DC., 248-277

6. Håkansson, K., U. Welander, and B. Mattiasson, 2005. Degradation of acetonitrile through a sequence of microbial reactors. Water Res. 39:648654.

7. Kobayashi, M., and S. Shimizu, 1998. Metalloenzyme nitrile hydratase: structure, regulation and application to biotechnology. Nat. Biotechnol. 16:733736.

8. Kohyama, I., A. Yoshimura, D. Aoshima, T. Yoshida, H. Kawamoto, and T. Nagasawa, 2006. Convenient treatment of acetonitrile-containing wastes using the tandem combination of nitrile hydratase and amidaseproducing microorganisms. Appl. Microbiol. Biotechnol. 72:600-606.

9. Miller, J.M. and E.E. Conn, 1980. Metabolism of hydrogen cyanide by higher plants. Physiologia Plantarum 65, 1199-1202

10. Meyer, O \& H.G. Schlegel, 1983. Biology of Aerobic Carbon Monoxide Oxidizing Bacteria. Annual Review Microbiology 37, 277-310

11. Miller, J.M. and E.E. Conn, 1980. Metabolism of hydrogen cyanide by higher plants. Physiologia Plantarum 65, 1199-1202

12. Marison, I.W. 1988. Growth Kinetics. Dalam: AH Scragg (Ed). Biotechnology for Engineers. Ellis Horwood
13. Manolov, T., K. Håkansson, and G. Benoit, 2005. Continuous acetonitrile degradation in a packed-bed bioreactor. Appl. Microbiol. Biotechnol. 66:567574. [PubMed].

14. Nawaz, M.S., T.M. Hienze, and C.E. Cerniglia, 1992. Metabolism of Benzonitrile and Butyronitrile by Klebsiella pneumoniae. Applied and Enviromental Microbiology, 58 (1):2731.

15. Pfennig, N. 1974. Rhodopseudomonas globiformis sp.n., A new species of the Rhodospirillaceae. Arch. Microbiology 100, 197-206.

16. Purnomo. 2000. Biokonversi akrilonitril menjadi akrilamida dan asam akrilat oleh sel Corynebacterium D5 (Skripsi). Fakultas Matematika dan IImu Pengetahuan Alam, Institut Pertanian Bogor.

17. Sorokin, D.Y., P van Sander,P.T. Tatjana, and M. Gerard, 2007. Microbial Isobutyronitrile Utilization under Haloalkaline Conditions. Applied and Environmental Microbiology 23 (17) : 5574-5579.

18. Sorokin, D. Y., S. van Pelt, T. P. Tourova, S. Takaichi, and G. Muyzer, 2007. Acetonitrile degradation under haloalkaline conditions by Natronocella acetinitrilica gen. nov., sp. nov. Microbiology 153:1157-1164.

19. Yamada H. and M. Kobayashi, 1996. Nitrile Hydratase and its application to industrial production of Acrylamide. Bioschi. Biotech. Biochem. 60 : 13911400. 